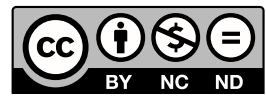

Estudos Teológicos foi licenciado com uma Licença Creative Commons Atribuição - NãoComercial - SemDerivados 3.0 Não Adaptada

http://dx.doi.org/10.22351/etv59i2.3767

\title{
ESTÉTICA DA RECEPÇÃO E MÉTODOS HISTÓRICO-CRÍTICOS: O TEXTO DA PERSPECTIVA DO LEITOR ${ }^{1}$
}

\author{
Aesthetics of reception and historical-critical methods: \\ the text from the reader's perspective
}

\begin{abstract}
José Adriano Filho²
Resumo: A estética da recepção representa um desafio para a pesquisa histórico-crítica da Bíblia, dominada pelas questões sobre as origens e história do texto. Este artigo procura demonstrar como, no final da década de 1960, com a estética da recepção ocorreu um deslocamento ao leitor no processo de interpretação dos textos literários. Os estudos de recepção, ao distanciarem-se dos paradigmas de interpretação da obra literária anteriores e proporem uma reflexão que enfatiza o receptor, o leitor, possibilitaram uma nova orientação aos estudos literários. As teorias estéticas anteriores, em geral, centralizavam-se mais na reconstrução histórica do texto bíblico, menos na história da interpretação e dos efeitos do texto. A contribuição da estética da recepção representa um dos esforços teóricos mais originais sobre a questão da leitura, entendida como uma prática cultural que se desenvolve a partir da interação entre a subjetividade de cada leitor e seu lugar social.
\end{abstract}

Palavras-chave: Estética da recepção. Métodos histórico-críticos. Horizonte de expectativas. Receptor.

Abstract: Aesthetics of reception presents a challenge to biblical historical-critical research, usually dominated by questions about the origins and history of the text. This paper seeks to demonstrate how, in the late 1960s, with Reception Studies a shift was made to the in the process of interpreting literary texts. Aesthetics of reception, by distancing itself from the paradigms of interpretation of the previous literary work of art and proposing a reflection that emphasizes the receptor, the reader, allowed a new orientation to the literary studies. Previous aesthetic theories have generally centered more on research dedicated to the historical reconstruction of the biblical text than to the history of interpretation and the effects of the text. The contribution of aesthetics of reception is one of the most original theoretical efforts related to the reading, understood as a cultural practice that develops from the interaction between the subjectivity of each reader and their social place.

Keywords: Aesthetics of reception. Historical criticism. Horizon of expectations. Receptor.

1 O artigo foi recebido em 30 de julho de 2019 e aprovado em 26 de agosto de 2019 com base nas avaliações dos pareceristas ad hoc.

2 Doutor. Faculdade Unida de Vitória, Vitória, ES. E-mail: j.adriano1@uol.com.br 


\section{Introdução}

No século XIX, o reconhecimento da dimensão histórica das realizações humanas deu início a uma revolução epistemológica. Nesse processo, a validade da forma de compreensão atomística e estática baseada na ideia de uma razão autônoma foi questionada por uma forma de compreensão dinâmica e orgânica fundada no fluxo da história. A razão histórica abriu horizontes que foram ampliados, inclusive, até aos nossos dias. ${ }^{3}$ Além disso, tomou-se consciência das dimensões linguísticas, éticas e sociais da historicidade da compreensão. No coração dessas pesquisas está o reconhecimento de que a produção e interpretação de um texto nunca ocorrem num vazio, pois essas atividades são sempre marcadas historicamente, ou seja, a produção e recepção de uma obra estão enraizadas na vida cultural de autoras/es e leitoras/es ${ }^{4}$.

Nesse período e no século seguinte, a pesquisa bíblica foi dominada pelo método histórico-crítico. Esse modelo de pesquisa demonstrou a distância histórica entre o texto e leitor e problematizou a questão de como um texto do passado poderia falar ao horizonte histórico presente. Com o seu desenvolvimento, a Escritura passou também a ser vista como fonte histórica e entendida de acordo com a forma de pensar de seus autores, no momento de sua composição, o que resultou numa profunda mudança da relação entre o intérprete e o texto bíblico. ${ }^{5}$ No desenvolvimento desse processo, atribuiu-se a esse método a capacidade de determinar o significado original dos textos bíblicos. $\mathrm{O}$ único a priori que esse modelo de pesquisa reconhecia era a lógica e os fatos ou dados empíricos que existem independentemente da observação e podiam ser validados objetiva e subjetivamente. Ao observar objetivamente os fatos da história, a sua meta era escapar da influência do seu horizonte histórico, tornando os pesquisadores cativos do seu próprio horizonte ao tentarem reconstruir objetivamente o passado. ${ }^{6}$

Nesse contexto, o surgimento da estética da recepção representa um desafio para a pesquisa bíblica dominada pelas questões referentes às origens, história e busca pelo significado original dos textos bíblicos. Com a estética da recepção, o estudo da obra de arte literária foi marcado por um deslocamento ao leitor, em especial a partir da apresentação, em 1967, da Aula Inaugural de Hans Robert Jauss na Universidade

3 REILL, Peter Hanns. The German Enlightenment and the Rise of the Historicism. Berkeley: University of California Press, 1975.

4 MORALES VÁSQUEZ, Victor Manuel. Contours of a Biblical Reception Theory. Studies in the Rezeptionsgeschichte of Romans 13.1-7. Göttingen: V \& R Unipress, 2012. p. 17.

5 Com o desenvolvimento da ciência moderna, a tradição eclesiástica não mais proporcionou, como antes, o contexto da interpretação bíblica. Imanuel Kant, na Crítica da Razão Pura (1781), procurou demonstrar as condições de construção do conhecimento: os limites e métodos que uma ciência legítima e universal pode e tem que trabalhar. Esse conceito de ciência foi transportado para a ciência histórica e provocou outra forma de investigar o passado através de uma análise crítica e criteriosa das fontes. O conceito indica que o ser humano assumiu uma nova posição frente à sua tradição literária ao perguntar pela autenticidade, veracidade e fidelidade das fontes. ADRIANO FILHO, José. O método histórico crítico e seu horizonte hermenêutico. Estudos de Religião, ano 22, n. 35, p. 28-39, jul./dez. 2008. p. 33.

6 PARRIS, David Paul. Reception Theory and Biblical Hermeneutics. Eugene, Oregon: Pickwick, 2009. p. 148-149. 
de Constança, que foi ampliada e publicada em 1971 com o título A história da literatura como provocação à ciência da literatura (Literaturgeschichte als Provokation der Literaturwissenschaft $)^{7}$. Esse deslocamento foi favorecido pela hermenêutica fenomenológica, que associava todo sentido a uma consciência. As teorias estéticas anteriores, em geral, centralizavam-se mais na produção, poucas vezes na recepção e comunicação da obra literária. A estética da recepção recupera "o papel genuíno do leitor, imprescindível tanto para o conhecimento estético como o histórico: o papel do destinatário a quem, primordialmente, a obra literária visa"8. Ao procurar explicar como se dá a leitura, inserem-na no contexto das práticas culturais de produção de sentido, construídas a partir do exercício interpretativo de sujeitos históricos que se localizam num determinado contexto social e espaço-temporal. ${ }^{9}$

\section{A estética da recepção}

Os métodos de interpretação da obra literária do final do século XIX e das primeiras décadas do século XX acentuavam a intenção do autor, remetiam a obra ao seu contexto original, destacavam a volta ao texto em sua imanência e enfatizavam sua linguagem literária autossuficiente, isto é, a face textual da obra, com desprezo para com seus elementos histórico-sociais. Havia também interpretações marxistas, que entendiam que sua tarefa era demonstrar o nexo da literatura em seu espelhamento da realidade social. Essas tendências, juntamente com o historicismo, não davam atenção ao leitor, considerado indispensável para a interpretação, pois somente por meio das experiências daqueles que leem e interpretam a mensagem dos textos as tradições literárias são formadas. Nesse contexto, Jauss buscava uma teoria que fizesse justiça ao "processo dinâmico de produção e recepção do autor, obra e público" e libertasse os estudos literários dos processos metodológicos secos e empoeirados. ${ }^{10}$

O interesse de Jauss pela recepção envolve a relação entre literatura e história. Sua atitude para com o estudo contemporâneo da literatura, apresentada em seu ensaio e em outras obras do período, é que faltava uma fundamentação teórica para o tratamento da literatura, especialmente em vista da crise que envolvia os modelos mais antigos de interpretação da obra literária. A concepção idealista de história havia recorrido a um princípio guia para ordenar os eventos e fatos, mas a alternativa maior a esse modelo historiográfico teleologicamente fundamentado surgiu com o historicismo do século XIX, que propagou o conceito de total objetividade. Mas o historicismo sacrifica a relevância da história pelo seu ideal de objetividade. Disso resultou, para os estudos literários, o aparecimento de metodologias que, em resposta à crise da historiografia, adotaram princípios que tornam a escrita da história literária problemática.

7 JAUSS, Hans Robert. A história da literatura como provocação à ciência da literatura. São Paulo: Ática, 1994.

8 JAUSS, 1994, p. 23.

9 ZILBERMAN, Regina. Estética da recepção e história da literatura. São Paulo: Ática, 1989. p. 50-51.

${ }_{10}$ JAUSS, 1994, p. 13-15; COSTA LIMA, Luiz. A literatura e o leitor. Textos de Estética da Recepção. 2. ed. Rio de Janeiro: Paz e Terra, 2002. p. 13. 
Ao imitar os métodos das ciências naturais, o positivismo tratou as obras literárias como se elas fossem consequências de causas mensuráveis e verificáveis. ${ }^{11}$

Para construir um novo modelo de história literária e solucionar a crise na história literária, Jauss, então, combina a exigência do marxismo pela mediação histórica, os avanços na esfera da percepção estética do Formalismo, um movimento linguístico e literário do início do século XX, e o conceito de fusão de horizontes de Hans George Gadamer. ${ }^{12}$ A força do marxismo é a ideia de que arte e literatura não são atividades independentes, mas parte do processo de vida. O marxismo vê a literatura como parte da apropriação humana do mundo e não adota uma atitude relativista ou não crítica para com a tradição. Mas Jauss não aceitava a ideia marxista do papel da produção na obra de arte, pois a recepção e os efeitos literários do texto para os leitores, ainda que importantes, eram secundários na teoria literária marxista; a literatura era reduzida à apropriação humana da natureza e o controle do processo econômico refletia apenas o que já é conhecido no horizonte social e histórico. Jauss questiona também a tese de que a literatura podia servir a uma função revolucionária, se se pode reconhecer apenas "as imagens estabilizadas e pré-conceitos de sua situação histórica", mas não reconhece que a literatura é capaz de criar novas perspectivas no mundo. ${ }^{13}$

O formalismo, ao acentuar o caráter artístico da literatura, desvincula "a obra literária de todas as condicionantes históricas e definiu a sua realização específica, como a soma de todos os procedimentos artísticos nela empregados"14. Os formalistas procuraram demonstrar que o texto é uma entidade estética que reflete a realidade através de suas próprias estruturas internas, empregando, para tal, ferramentas como a diferença entre a linguagem poética e a linguagem prática dos textos; o estranhamento; a relação entre história e enredo e a evolução literária. ${ }^{15}$ Do formalismo, Jauss retém a capacidade da literatura de romper com a linguagem cotidiana e compreender, via estranhamento, a diferença entre linguagem prática e poética. Os textos literários fazem isso ao provocar o estranhamento entre a nossa compreensão de mundo e a apresentação de formas novas e inesperadas. A oposição entre o mundo apresentado no texto (linguagem poética) e realidade (linguagem prática) dá ao leitor a base necessária para comparar o que o texto apresenta com as suas próprias expectativas. ${ }^{16}$

Jauss reconhece também que o formalismo introduziu uma perspectiva diacrônica nos estudos literários por meio do conceito de evolução das formas literárias, funções e gêneros. A historicidade da literatura está presente na construção do seu método, pois apresenta o problema que o obrigou a pensar os princípios da diacronia: "O literário na literatura não é determinado apenas sincronicamente, mas é também

${ }^{11}$ HOLUB, Robert C. Reception Theory. A critical introduction. London; New York: Methuen, 1984. p. 54-55.

12 JAUSS, Hans Robert. Estética da Recepção: Colocações Gerais. In: COSTA LIMA, 2002, p. 78.

${ }_{13}$ PARRIS, 2009, p. 121-122.

${ }_{14}$ JAUSS, 1994, p. 18; HOLUB, 1984, p. 16-18.

${ }^{15}$ ERLICH, Victor. Formalism: History - Doctrine. 4 ed. The Hague, Paris: Mouton, 1980. p. 171-191; PARRIS, 2009, p. 123.

${ }^{16}$ PARRIS, 2009, p. 123-125. 
diacronicamente, por sua oposição àquilo que lhe é predeterminado pelo gênero e à forma que o precede na história literária." $17 \mathrm{O}$ formalismo ensina-nos "a ver de maneira nova a obra de arte em sua história, isto é, na transformação dos sistemas de gêneros e formas literárias, abrindo caminho para a descoberta de que a pura sincronia é ilusória", porque "todo sistema apresenta-se necessariamente como uma evolução, e esta, por sua vez, carrega forçosamente um caráter sistemático" "18. A ideia de mudança e desenvolvimento na literatura, que envolve combinação histórica e significado artístico, tem um papel central na teoria da recepção. ${ }^{19}$

Além da exigência do marxismo pela mediação histórica e dos avanços na esfera da percepção estética do formalismo para a construção de uma nova história literária, Jauss considera também o conceito de "horizonte de expectativa", de Hans George Gadamer, cujo livro Verdade e Método integra as contribuições da filosofia alemã referentes ao papel da história e linguagem na existência e compreensão humanas. ${ }^{20}$ Para Gadamer, a compreensão é um evento, isto é, ela ocorre na história e na linguagem. Isso significa uma mudança de paradigma radical, que se contrapõe às teorias que privilegiavam a aplicação do método, considerado como o único meio válido de acesso à verdade. $\mathrm{O}$ conceito de método estava baseado no modelo epistemológico sujeito-objeto, por meio do qual o sujeito aplica o método de forma não problematizada ao objeto de investigação para obter a verdade. A realidade tornou-se um objeto de investigação a ser apreendido por um sujeito presumivelmente dela afastado. Gadamer não iguala a verdade a resultados metodológicos. Para ele, a compreensão como forma primeira de ser no mundo é a condição a priori para qualquer atividade científica.

A experiência hermenêutica histórica difere radicalmente do conceito de experiência como experimento das ciências naturais. Os experimentos pressupõem repeti-

17 JAUSS, 1994, p. 19.

18 JAUSS, 1994, p. 19-20.

${ }_{19}$ PARRIS, 2009, p. 126.

${ }^{20}$ GADAMER, Hans George. Verdade e Método I. Traços fundamentais de uma hermenêutica filosófica. 3. ed. Petrópolis: Vozes, 2007. Nessa obra, Gadamer analisa as diversas correntes do pensamento hermenêutico clássico e questiona o método e sua relação com a verdade e, para tornar a tarefa da hermenêutica mais plausível, insere duas narrativas filosóficas no livro. A primeira, influenciada por Heidegger, conta a história da tradição filosófica ocidental na forma de uma queda da graça e a possibilidade futura de redenção. Num tempo pré-cartesiano, o método científico ainda não havia dominado o conceito de verdade. Sujeito e objeto, ser e pensamento, não estavam radicalmente separados um do outro como ocorreu mais tarde. Mas com o advento do dualismo cartesianismo, a alienação do ser humano ocidental, que já tinha sido detectada antes de Descartes, tornou-se o pilar da filosofia ocidental. A tarefa não declarada da atividade especulativa do século XVII ao século XX tem sido esconder e justificar a alienação entre mente e coisa, sujeito e objeto ao fornecer uma base filosófica para o método científico. A segunda narrativa, a história da hermenêutica, apresenta conclusões similares, mas com um enredo um pouco diferente, pois a hermenêutica é geralmente associada por Gadamer com a oposição ao pensamento científico dominante. Ela está também conectada com a arte, pois Gadamer vê, em geral, o exemplo da arte como paradigmático para o conceito de compreensão. Ele entende que o começo desta história está na era pré-romântica com a tradição da exegese bíblica e humanista, pois as origens da hermenêutica estão intimamente ligadas à preocupação em descobrir o sentido correto dos textos. Se acrescentarmos a interpretação legal a essas duas tradições, entendemos porque a hermenêutica pré-romântica é apresentada como subtilitas intelligendi (compreensão), subtilitas explicandi (explicação) e subtilitas applicandi (aplicação). Cf. HOLUB, 1984, p. 37-39. 
bilidade das experiências por meio de procedimentos controlados, mas na experiência hermenêutica histórica cada nova experiência é fundida com uma experiência prévia. Essas experiências integradas constitui a dimensão pré-teorética do evento da compreensão. Nossa pertença à história não permite pensar num conhecimento imparcial garantido pela aplicação do método, e nossa localização numa situação histórica específica possibilita a abertura aos legados culturais que nos precedem. A distância histórica é uma instância produtiva: a história efectual é uma instância histórica de criação futura e o desdobramento de múltiplas possibilidades e promessas por meio da relação dialógica entre leitores e textos. ${ }^{21}$

Tradição e pré-compreensão são instâncias socio-históricas do princípio da história efectual. O passado é parte do nosso ser e a aplicação do método não separa o intérprete do seu objeto de investigação devido à sua pertença à tradição. A pré-compreensão é também um elemento constitutivo da existência humana e, como tal, as pré-compreensões que herdamos tampouco são, por sua natureza, negativas ou positivas. Georgia Warnke afirma: "antes de, conscientemente, começar a interpretar um texto ou captar o significado de um objeto, eu já o coloquei dentro de certo contexto (Vorhabe), aproximei-o de certa perspectiva (Vorsicht) e o concebi de certa maneira

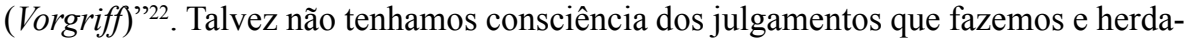
mos da tradição, mas é isso que constitui nosso horizonte de compreensão. Nós nos tornamos conscientes de que pertencemos a uma tradição e, quando aceitamos essa premissa, podemos avaliar como nossa pré-compreensão dá forma à maneira como compreendemos o passado. $\mathrm{O}$ ato de compreensão ocorre nos limites de nossos hábitos, linguagens e tradição e envolve possíveis projeções para a compreensão. ${ }^{23}$

Tradição e pré-compreensão representam, portanto, dois elementos cruciais reabilitados no argumento de Gadamer frente às afirmações de autonomia da razão. Numa tentativa de superar todo tipo de autoridade e rejeitar toda obediência cega, o iluminismo eliminou inteiramente essa possibilidade epistemológica. Gadamer, ao contrário, fundamenta o conceito de autoridade no reconhecimento da superioridade do outro. Esse reconhecimento implica admitir a própria limitação à luz de uma melhor compreensão dos outros.$^{24}$ Como não escapamos de nossa situação histórica, a compreensão sempre é uma tarefa incompleta. Horizonte, o lugar de onde nos aproximanos do tema a ser interpretado, implica olhar além do que está dado e indica o mundo da vida histórica dos leitores e textos que estão em constante movimento. O horizonte do texto e o horizonte dos leitores atuais, que é parte e parcela de qualquer empreendimento acadêmico, nunca existem como entidades claramente definidas. No diálogo entre o passado e o presente, a distância temporal entre o intérprete é preenchida com o nome de fusão de horizontes, tornando-se um aspecto importante da interpretação.

No contexto do surgimento da estética da recepção, portanto, o desafio da interpretaçao da obra literária estava na retomada do problema da história da literatura

${ }^{21}$ MORALES VÁSQUEZ, 2012, p. 19-20.

${ }^{22}$ WARNKE, Georgia. Gadamer, Hermeneutics, Tradition and Reason. Oxford: Polity, 1987. p. 77.

${ }^{23}$ PARRIS, 2009, p. 3-4.

${ }^{24}$ MORALES VÁSQUEZ, 2012, p. 21-22. 
deixado em aberto pela disputa entre os métodos marxista e o formalista. Jauss critica essas escolas, mas apropria-se também de algumas de suas contribuições. Ele as critica por achar que elas privam a literatura de um componente "imprescindível tanto de seu caráter estético quanto de sua função social: a dimensão de sua recepção e de seu efeito, pois leitores, ouvintes, espectadores - o fator público desempenha nessas teorias literárias um papel extremamente limitado". Mas Jauss combina a exigência do marxismo pela mediação histórica, os avanços na esfera da percepção estética e o conceito de fusão de horizontes de Gadamer. Para ele, a obra literária é "condicionada primordialmente pela relação dialógica entre literatura e leitor", com implicações estéticas e históricas. A implicação estética "reside no fato de já a recepção primária de uma obra pelo leitor encerra uma avaliação de seu valor estético, pela comparação com outras obras já lidas"; a implicação histórica "manifesta-se na possibilidade de, numa cadeia de recepções, a compreensão dos primeiros leitores ter continuidade e enriquecer-se de geração em geração, decidindo, assim, o próprio significado histórico de uma obra e tornando visível sua qualidade estética"25.

\section{Horizonte de expectativas: o encontro do leitor com o texto}

A pesquisa bíblica histórico-crítica reconhece que o intérprete está ligado ao seu horizonte histórico, mas procura superar essa restrição ao "colocar entre parênteses" o horizonte do intérprete. O único a priori que ela reconhece é a lógica e os fatos ou dados empíricos que existem independentemente da observação e podem ser validados objetiva e subjetivamente. Ao observar objetivamente os fatos da história, sua meta é escapar da influência do seu horizonte histórico. ${ }^{26}$ Esse ideal da objetividade histórica está presente, por exemplo, nas grandes séries de comentários que interpretam a Bíblia como um texto antigo, como uma relíquia do passado que está sujeita a uma análise técnica objetiva. ${ }^{27}$ Exige-se do intérprete a interpretação filológica, gramatical e histórica para a compreensão do texto, o que reduz a interpretação a uma forma de tradução.

Gadamer e Jauss entendem que a compreensão não está mais garantida. Em oposição à perspectiva da escola histórica positivista que buscava superar a distância histórica entre os dois horizontes por meio da objetividade prometida por uma aproximação metodológica, Gadamer fundamenta a fusão de horizontes na realidade da distância histórica. A possibilidade de uma compreensão fecunda está na distância temporal entre os horizontes, que permite ao intérprete perceber a estranheza do texto antes que ocorra a fusão entre os dois horizontes. ${ }^{28}$ Isso permite a alteridade do texto

\footnotetext{
25 JAUSS, 1994, p. 23.

26 "Whoever believes that it is possible to arrive at the other horizon, that of some prior time, by simple disregarding one's own inevitably introduces subjective criteria concerning selection, perspective, and evaluation into his supposedly objective reconstruction of the past" (JAUSS, 1989, p. 198).

27 PARRIS, 2009, p. 148-149.

28 "Whereas experience can organize the past into a special and perspectival whole, expectation is directed at the open horizon of individual, not yet realized possibilities" (JAUSS, 1989, 202).
} 
como forma de avaliação da pré-compreensão do intérprete e para que a interpretação seja uma experiência que mude o intérprete. Jauss, partindo dessa perspectiva, desenvolve o conceito de horizonte de expectativas, entendendo-o como um sistema de referências "ou uma mentalidade que um indivíduo hipotético poderia trazer para qualquer texto" 29 . A implicação desse conceito para a hermenêutica envolve uma mudança da compreensão e interpretação do texto como artefato histórico para uma compreensão como uma sondagem do significado possível que surge da fusão de horizontes.

$\mathrm{O}$ conhecimento prévio à experiência da leitura está relacionado com aquilo que o leitor espera no encontro com a obra, que se refere, principalmente, mas não exclusivamente, às expectativas que ele traz para o texto. ${ }^{30}$ Nesse sentido, pode-se falar de dois horizontes que condicionam o sentido de um texto: o horizonte da leitura e o horizonte social. O horizonte de expectativas da leitura é um sistema de referências dos gêneros, formas e temas de uma obra adquiridos por meio da leitura de obras já conhecidas. O receptor aproxima-se de uma obra com uma ideia prévia do que pode encontrar nela. O novo texto evoca no leitor o horizonte de expectativas que lhe é familiar a partir de textos anteriores. O horizonte de expectativas social dirige-se ao receptor e refere-se à sua compreensão prévia do mundo, que "inclui suas expectativas concretas procedentes do horizonte de seus interesses, desejos, necessidades e experiências, condicionado pelas circunstâncias sociais, as específicas de cada estrato social e, também, as biográficas" 31 . Cada leitor está situado num tempo e espaço específicos e, portanto, se apropria, interpreta e atualiza um texto de maneira única. Cada leitor aproxima-se da obra literária a partir de suas interpretações anteriores e das concepções que tem da obra em seu entorno social.

Essa diversidade de expectativas enriquece a experiência de leitura porque provoca novas perspectivas em torno da obra literária, ou seja, ela pode ser observada a partir de vários pontos de vista que geram matizes diferentes. Essa variedade cromática desenha-se com um receptor ativo, que estabelece um diálogo com a obra e com o autor. A aproximação do receptor à obra sempre coloca perguntas novas, que desvela outros significados da obra e, inclusive, pode chegar a questionar as normas que ela transmite. Em algumas ocasiões, o receptor propicia uma mudança ao propor novas normas a partir do encontro com a obra e é capaz de tornar-se criador. Jauss entende o horizonte de expectativas literário como o efeito, ou seja, o elemento de concretização de sentido condicionado pelo texto, e horizonte de expectativas social

29 PARRIS, 2009, p. 150; HOLUB, 1984, p. 59.

30 "Every experience has its horizon of expectation: all consciousness exists as consciousness of something, and thus, always also, exists within the horizon of already formulated ans still forthcoming experiences [...] Experience is formed in the functional swing from anticipation (preconception) to the fulfillment or disappointment of the anticipation. Even the new that is unexpected is 'new in the context of a certain knowledge'; within the horizon of disappointed expectation, it becomes something that can be experienced, something that opens a new horizon, and thus demonstrates that 'every actual horizon [...] (has) within it a system of potential horizons"' (JAUSS, Hans Robert. Question and Answer: Forms of Dialogical Understanding. Minneapolis: University of Minnesota Press, 1989. p. 203-204).

31 JAUSS, 1987, p. 77. 
como a recepção, que se refere ao elemento dessa mesma concretização condicionado pelo destinatário. ${ }^{32}$

A concretização é o processo de interação do leitor com o texto, em que "este atua como pauta e tudo o que não diz ou silencia cria vazios que forçam aquele a interferir criadoramente do texto, a dialogar com ele, de igual para igual, num ato de comunicação" "33. A atitude de interação tem como pré-condição o fato de que texto e leitor estão mergulhados em horizontes históricos, muitas vezes distintos e defasados, que precisam fundir-se para que a comunicação ocorra. ${ }^{34}$ No ato de produção/ recepção ocorre a fusão de horizontes de expectativas, pois as expectativas do autor se traduzem no texto e as expectativas do leitor são a ele transferidas. O texto torna-se o campo em que os dois horizontes podem identificar-se ou estranhar-se, razão pela qual se pode tomar a relação entre as expectativas do leitor e a obra em si como parâmetro para a avaliação estética da literatura. ${ }^{35} \mathrm{O}$ horizonte de expectativas pode, portanto, vincular a produção artística com a recepção do destinatário. A ponte que se estende entre a dimensão intraliterária e a dimensão social dá-se por meio da fusão de horizontes, esse encontro entre mundos, suas modalidades e as consequências que pode provocar. ${ }^{36}$

Ainda que muitas vezes a fusão de horizontes occora devido ao fato de que a obra cumpre as expectativas do leitor, em outras ocasiões o horizonte de expectativas literário não satisfaz ao público ou não é compreendido por esse grupo de leitores. A distância estética, que determina o carácter artístico de uma obra, é precisamente o choque que gera um novo horizonte em relação ao horizonte prévio e provoca o surgimento das novas perspectivas da obra. ${ }^{37}$ A reação do primeiro público é também fundamental para estabelecer o valor estético da obra. A obra pode produzir satisfação, superar, decepcionar ou frustrar as expectativas de um público num momento histórico específico ${ }^{38}$ e, a partir dessa primeira reação, começa-se a escrever a sua história. Uma mudança de horizonte implica um movimento do familiar ao estranho, permitindo ampliar e enriquecer o próprio horizonte de expectativas. $\mathrm{O}$ novo horizonte proposto pelo texto pode questionar as ideias preconcebidas do leitor, levá-lo a refletir sobre temas diferentes, libertá-lo das restrições cotidianas e, com isso, dar-lhe uma nova perspectiva de mundo.

32 JAUSS, 1987, p. 77.

${ }^{33}$ BORDINI, M. G.; AGUIAR, V. T. A formação do leitor. Alternativas Metodológicas. Porto Alegre: Mercado Aberto, 1988. p. 82.

34 BORDINI; AGUIAR, 1988, p. 83.

35 JAUSS, 1994, p. 30.

36 JAUSS, 1987, p. 77.

37 "O horizonte de expectativa de uma obra, que assim se pode reconstruir, torna possível determinar seu caráter artístico a partir do modo e do grau segundo o qual ela produz seu efeito sobre um suposto público. Denominando-se distância estética aquela que medeia entre o horizonte de expectativa preexistente e a aparição de uma obra nova - cuja acolhida, dando-se por intermédio da negação de experiências conhecidas ou da conscientização de outras, jamais expressas, pode ter por consequência uma "mudança de horizonte" -, tal distância estética deixa-se objetivar historicamente no espectro das reações do público e do juízo da crítica (sucesso espontâneo, rejeição ou choque, casos isolados de aprovação, compreensão gradual ou tardia)" (JAUSS, 1994, p. 30).

38 JAUSS, 2013, p. 180. 
O horizonte de expectativas da literatura pode também ampliar a experiência, permitindo ao leitor abrir-se a experiências ainda não realizadas.

O foco central de toda interpretação textual deve, portanto, recair sobre o leitor e seus processos de recepção, não somente no autor e nos mecanismos de concepção da obra literária. O leitor é um produtor de interpretações e significações válidas. Todo signo passível de leitura não é uma reprodução, reflexo dos eventos sociais que possibilitaram sua concepção, mas um construto social e cultural que, a partir de sua historicidade, desempenha um papel ativo na produção das possíveis interpretações de cada leitor, na medida em que envolve e ativa suas estruturas intelectuais, emotivas e sensoriais. Esse leitor é uma figura histórica que respeita a história do signo que lê, mas que ao mesmo tempo promove uma ruptura com as leituras feitas até aquele momento, empreendendo sua própria interpretação da obra que lhe é apresentada. Como a categoria "horizonte de expectativa" é vista como uma mistura dos códigos vigentes e da soma de experiências sociais acumuladas, ela envolve também o conceito de emancipação, entendido como a finalidade e os efeitos alcançados pela arte, que libera seus destinatários das percepções usuais e confere-lhes nova visão da realidade. ${ }^{39}$ As expectativas são direcionadas a novas experiências que podem abrir nosso horizonte de expectativas baseado em nossas experiências prévias. A espiral hermenêutica continua na medida em que surgem novos horizontes de expectativas que permitirão perspectivas diferentes, as quais, por sua vez, serão corrigidas e modificadas. É ingenuidade pensar que podemos entender outro horizonte se desconsiderarmos nosso próprio horizonte. ${ }^{40}$

\section{Perguntas apropriadas ao conteúdo do texto e novos desafios aos leitores}

A história da recepção de um texto é o resultado do desdobramento do seu significado potencial. A "reserva de significado" do texto localiza-se em seu horizonte original e no horizonte do intérprete. O significado origina-se na interação do texto com as sucessivas gerações de leitores. Os textos utilizam sinais, gêneros e outros elementos familiares a leitores. Além disso, o evento da experiência estética não é uma experiência subjetiva arbitrária. Há um horizonte intersubjetivo que determina os efeitos ou influência de um texto. Os textos empregam convenções herdadas de outros textos pelos leitores, que se tornam parte das formas da vida ou dos seus jogos de linguagem, fazendo com que o efeito de um texto não seja um evento privado, mas intersubjetivo. Por essa razão, a obra literária próxima ao horizonte de expectativa dos leitores e que não provoca uma mudança de horizonte foi classificada por Jauss como "arte culinária ou ligeira". Se não somos provocados pela obra de arte, não temos uma experiência. ${ }^{41}$

A aproximação do receptor à obra sempre coloca perguntas novas, que desvelam outros significados da obra e, inclusive, podem chegar a questionar as normas que

\footnotetext{
39 ZILBERMAN, 1989, p. 49-50.

40 PARRIS, 2009, p. 150-151.

${ }^{41}$ PARRIS, 2009, p. 134.
} 
ela transmite. As possibilidades de diálogo com a obra dependem também do grau de identificação ou de distanciamento do leitor em relação a ela, no que diz respeito às convenções sociais e culturais a que está vinculado e à consciência que delas possui. Uma obra pode solidificar o sistema de valores e normas do leitor, mantendo o seu horizonte de expectativas inalterado e tornando confortável sua posição psicológica. Há, contudo, obras literárias que desafiam a compreensão por se afastarem do que é esperado pelo leitor. Nesse caso, podem afastá-lo da obra ao exigir um esforço de interação muito conflitivo com seu sistema de referências vitais. ${ }^{42}$

$\mathrm{O}$ resgate de um texto de sua redução à arte culinária exige um esforço especial para lê-lo a "a contrapelo" da experiência que se fez hábito e, assim, divisar-lhe novamente o caráter artístico" 43 . Por exemplo, o caráter subversivo das parábolas apresentado na "negação" da parábola do bom samaritano (Lc 10.25-37), não é mais reconhecido em nosso horizonte de expectativas. O título "bom samaritano" que foi acrescentado à parábola o indica. Foi o choque experimentado pelos seus primeiros ouvintes que provocou a inversão de suas expectativas em torno da identidade do herói da história, o oposto do nosso horizonte de expectativas. ${ }^{44}$ Essa inversão de expectativa relembra o apelo como provocação e crítica que, na tradição bíblica, vem do outro nas feições do perseguido, do proscrito (pobres, diaristas, viúvas, órfãos, estrangeiros). O outro rompe a minha totalidade e o meu anseio de segurança, quando, na sua palavra, diz: "Não matarás", "tenho fome", "tenho sede". Na inversão que Jesus faz da pergunta do escriba: “Quem é o meu próximo?", depois mostrar que somente o samaritano agiu com misericórdia para com a pessoa necessitada, ele pergunta: "Qual destes três ter parece ter sido o próximo do homem que caiu nas mãos dos salteadores?”. Jesus refaz a pergunta: “Quem foi que se fez próximo”. Eu não tenho próximo, eu me torno próximo.

Sem provocação, jamais aprenderemos a reconhecer o que não sabemos, a aprender e a perguntar e nos desenvolver como pessoas, comunidades e tradições. Ao mesmo tempo, a tradição tem o poder de nivelar ou de homogeneizar até mesmo as obras mais provocadoras e inovadoras. A distância estética entre o texto e a audiência

\footnotetext{
42 "A maneira pela qual uma obra literária, no momento histórico de sua aparição, atende, supera, decepciona ou contraria as expectativas de seu público inicial oferece-nos claramente um critério para a determinação de seu valor estético. A distância entre o horizonte de expectativa e a obra, entre o já conhecido da experiência estética anterior e a "mudança de horizonte" exigida pela acolhida à nova obra, determina, do ponto de vista da estética da recepção, o caráter artístico de uma obra literária. À medida que essa distância se reduz, que não se demanda da consciência receptadora nenhuma guinada rumo ao horizonte da experiência ainda desconhecida, a obra se aproxima da esfera da arte 'culinária' ou ligeira. Esta última deixa-se caracterizar, segundo a estética da recepção, pelo fato de não exigir nenhuma mudança de horizonte, mas sim de simplesmente atender a expectativas que delineiam uma tendência dominante do gosto, na medida em que satisfaz a demanda pela reprodução do belo usual, confirma sentimentos familiares, sanciona as fantasias do desejo, torna palatáveis - na condição de "sensação" - as experiências não corriqueiras ou mesmo lança problemas morais, mas apenas para "solucioná-los" no sentido edificante, qual questões já previamente decididas" (JAUSS, 1994, p. 31-32).

43 JAUSS, 1994, p. 32.

44 PARRIS, 2009, p. 134-135; ADRIANO FILHO, José. Estética da Recepção e Hermenêutica Bíblica. In: NOGUEIRA, Paulo A. S. (Org.). Linguagens da Religião. São Paulo: Paulus, 2012. p. 181.
} 
original é menor para os leitores posteriores "até ao ponto em que a negatividade original da obra se torna autoevidente, entrando no horizonte da experiência estética

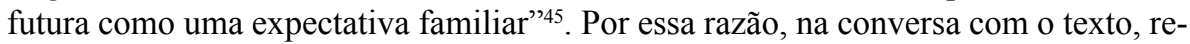
alizada por meio das perguntas que lhe fazemos, na passagem de um contexto cultural a outro, que o texto ganha novas significações, que nem seu autor nem os primeiros leitores haviam previsto. As respostas oferecidas pelos textos dependem também das questões que lhe dirigimos do nosso ponto de vista histórico e da nossa capacidade de reconstruir a questão à qual o texto responde. A reconstrução do conjunto de perguntas que os leitores/intérpretes fazem ao texto a partir de um horizonte histórico específico é um passo significativo na estética da recepção.

As obras literárias oferecem também soluções possíveis às questões colocadas pelos textos anteriores e apresentam novas questões. O "novo" não é mera inovação literária, mas uma categoria estética, que ocorre quando um autor se apropria do passado ou apresenta uma leitura nova ou inesperada da literatura passada em sua obra, nela encontrando algo que não tinha sido buscado antes. Esse aspecto é relevante para os estudos bíblicos, em especial as questões que envolvem as relações intertextuais e históricas, por exemplo, nos evangelhos sinóticos: Qual foi o primeiro evangelho a ser escrito? Como os autores subsequentes editaram ou expandiram as tradições prévias sobre a vida de Jesus a que tiveram acesso? Qual o lugar dos diferentes comentários nas "séries" de interpretação bíblica? Comentários e interpretações não só respondem às questões do significado do texto, mas também apresentam questões para futuros comentaristas. A história da recepção da Bíblia envolve as respostas dadas às perguntas que ela faz e que têm moldado a tradição cristã por causa de seu caráter exemplar, bem como as respostas ilegítimas dadas e que devem ser evitadas pelos intérpretes futuros. ${ }^{46}$

A literatura não é o produto das influências sociais que servem como repositório da cultura, pois também desempenha uma função socialmente formativa. Não é somente produto das condições sociais, mas também agente de mudança social. A função socialmente formativa ou normativa da literatura é significativa para a interpretação bíblica, que resultou em práticas que resultaram em profundas consequências tanto positivas quanto negativas. Nesse sentido, Ulrich $\mathrm{Luz}^{47}$ afirma que o fato de o texto possuir um poder socialmente formativo, em particular os textos teológicos, torna-se

45 "Se, inversamente, trata-se de avaliar o caráter artístico de uma obra pela distância estética que a opõe à expectativa de seu público inicial, segue-se daí que tal distância - experimentada de início com prazer ou estranhamento, na qualidade de uma nova forma de percepção - poderá desaparecer para leitores posteriores, quando a negatividade original da obra houver se transformado em obviedade e, daí em diante, adentrado ela própria, na qualidade de uma expectativa familiar, o horizonte da experiência estética futura. É nessa segunda mudança de horizonte que se situa particularmente a classicidade das assim chamadas obras-primas; sua forma bela, tornada uma obviedade, e seu "sentido eterno", aparentemente indiscutível, aproximam-se perigosamente, do ponto de vista estético-recepcional, da pacificamente convincente e palatável arte "culinária", de forma que um esforço particular se faz necessário para que se possa lê-la "a contrapelo" da experiência que se fez hábito e, assim, divisar-lhe novamente o caráter artístico" (JAUSS, 1994, p. 32).

${ }^{46}$ PARRIS, 2009, p. 140-141; ADRIANO FILHO, 2012, p. 181-182.

${ }^{47}$ LUZ, Ulrich. Mathew in History: Interpretation, Influence, and Effects. Minneapolis: Fortress, 1994. 
necessário uma "hermenêutica de consequências". Para esse tipo de hermenêutica, o estudo da história dos efeitos do texto é essencial, porque ela mostra as consequências das leituras dos textos bíblicos na história. A interpretação de Lutero de Romanos 1.17 é o exemplo paradigmático de interpretação bíblica na tradição protestante. Mas é preciso lembrar que a função socialmente formativa nem sempre é emancipatória. Mateus 27.25: "A isso todo o povo respondeu: 'O seu sangue caia sobre nós e sobre nossos filhos", demonstra a maneira na qual se pode abusar de um texto ou mal interpretá-lo. A interpretação desse verso foi usada para fundamentar a perseguição aos judeus. "A história dos efeitos mostra que os textos têm poder e, portanto, não pode ser separada de suas consequências. Interpretar um texto não é somente jogar com as palavras, mas um ato com consequências históricas." ${ }^{\text {"48 }}$ Nesse caso não se trata de uma experiência genuína de diálogo com o texto, mas um efeito produzido pela recepção do texto que moldou a história da tradição cristã e que necessita ser incluída na sua história efectual (Wirkungsgeschichte) ${ }^{49}$.

\section{Conclusão}

Este artigo procurou demonstrar que a historicidade da compreensão de um texto literário e de seus leitores é a proposição básica da estética da recepção. O leitor, como agente, precisa tornar o sentido do texto concreto. No caso dos textos bíblicos, o objeto dos estudos de recepção é a história da sua recepção do texto bíblico, apropriação e impacto na vida de leitores. Da perspectiva da recepção, a leitura realizada pelo método histórico-crítico não tem uma posição de destaque, nem é o critério final de avaliação. A estética da recepção privilegia as condições de leitura do texto pelos seus leitores, não a reconstrução de como a obra foi produzida, isto é, não procura determinar o significado original do texto pretendido pelo autor, mas demonstrar como o significado de um texto se desdobra historicamente.

A estética da recepção, portanto, distancia-se dos paradigmas que se centralizam mais na produçao da obra literária ou do texto bíblico, mas raramente examina o aspecto receptivo e comunicativo do texto. Ela entende que a obra se evidencia durante as intervenções de leitores no processo de leitura. No diálogo entre a obra e o receptor é que ocorrem a interpretação e a recepção, pois quando um receptor se aproxima da obra, ele o faz a partir de um contexto impregnado de interpretações prévias. Há uma interação entre o texto e o mundo da vida dos leitores. Os textos são também compreendidos por meio de outros textos, que constituem suas interpretações. Eles oferecem respostas complexas a problemas complexos. Não há uma resposta totalmente direta. A exegese bíblica procura explicar o texto, há comentários exegéticos que oferecem leituras técnicas do texto, mas a história da interpretação do texto bíblico envolve também as instâncias de sua recepção. Não podemos igualar o significado

\footnotetext{
${ }^{48}$ LUZ, 1994, p. 33.

${ }^{49}$ ADRIANO FILHO, 2012, p. 187.
} 
do texto à intenção autoral e desconsiderar o papel dos leitores, que dialogam com o texto e demonstram a historicidade da compreensão.

\section{Referências}

ADRIANO FILHO, José. O método histórico crítico e seu horizonte hermenêutico. Estudos de Religião, ano 22, n. 35, p. 28-39, jul./dez. 2008.

ADRIANO FILHO, José. Estética da Recepção e Hermenêutica Bíblica. In: NOGUEIRA, Paulo A. S. (Org.). Linguagens da Religião. São Paulo: Paulus, 2012. p. 165-190.

BORDINI, M. G.; AGUIAR, V. T. A formação do leitor. Alternativas Metodológicas. Porto Alegre: Mercado Aberto, 1988.

COSTA LIMA, Luiz. A literatura e o leitor. Textos de Estética da Recepção. 2. ed. Rio de Janeiro: Paz e Terra, 2002.

ERLICH, Victor. Formalism: History - Doctrine. 4. ed. The Hague, Paris: Mouton Publishers, 1980.

GADAMER, Hans George. Verdade e Método I. Traços fundamentais de uma hermenêutica filosófica. 3. ed. Petrópolis: Vozes, 2007.

HOLUB, Robert C. Reception Theory. A critical introduction. London; New York: Methuen, 1984. JAUSS, Hans Robert. A história da literatura como provocação à ciência da literatura. Trad. Sérgio Tellaroli. São Paulo: Ática, 1994.

JAUSS, Hans Robert. Question and Answer: Forms of Dialogical Understanding. Minneapolis: University of Minnesota Press, 1989.

LUZ, Ulrich. Mathew in History: Interpretation, Influence, and Effects. Minneapolis: Fortress, 1994.

MORALES VÁSQUEZ, Victor Manuel. Contours of a Biblical Reception Theory. Studies in the Rezeptionsgeschichte of Romans 13.1-7. Göttingen: V \& R Unipress, 2012.

PARRIS, David Paul. Reception Theory and Biblical Hermeneutics. Eugene, Oregon: Pickwick, 2009.

REILL, Peter Hanns. The German Enlightenment and the Rise of the Historicism. Berkeley: University of California Press, 1975.

WARNKE, Georgia. Gadamer, Hermeneutics, Tradition and Reason. Oxford: Polity, 1987.

ZILBERMAN, Regina. Estética da recepção e história da literatura. São Paulo: Ática, 1989. 